\title{
Journal of Plant Pathology \& Microbiology
}

\section{Effect of Temperatures and Culture Media on Sclerotium rolfsii Mycelial Growth, Sclerotial Formation and Germination}

Fakher Ayed ${ }^{1,2,3^{*}}$, Hayfa Jabnoun-Khiareddine ${ }^{3}$, Rania Aydi Ben Abdallah ${ }^{3}$ and Mejda Daami-Remadi ${ }^{3}$

${ }^{1}$ Technical Centre of Organic Agriculture, Chott-Meriam, Sousse, Tunisia

${ }^{2}$ National Agronomic Institute of Tunisia, University of Carthage, Tunisia

${ }^{3}$ UR13AGR09-Integrated Horticultural Production in the Tunisian Centre-East, Regional Research Centre on Horticulture and Organic Agriculture, University of Sousse, Chott-Mariem, Tunisia

"Correspondence: Fakher Ayed, UR13AGR09-Integrated Horticultural Production in the Tunisian Centre-East, Regional Research Centre on Horticulture and Organic Agriculture, University of Sousse, Tunisia, Tel: 0021673327543; E-mail: ayedfakher@yahoo.fr

Rec date: July 17, 2018; Acc date: August 23, 2018; Pub date: August 31, 2018

Copyright: (C) 2018 Ayed F, et al. This is an open-access article distributed under the terms of the creative commons attribution license, which permits unrestricted use, distribution, and reproduction in any medium, provided the original author and source are credited.

\begin{abstract}
Sclerotium rolfsii is a serious soilborne phytopathogenic fungus causing serious yield loss in crops of high economic importance. In this study, the effects of temperatures and culture media were evaluated on $S$. rolfsii mycelial growth, sclerotial production and germination. The three isolates tested grew over a range of temperatures from $10^{\circ} \mathrm{C}$ to $35^{\circ} \mathrm{C}$ but not at $5^{\circ} \mathrm{C}$ and $40^{\circ} \mathrm{C}$. Radial growth and dry mycelium production were highest at $30^{\circ} \mathrm{C}$. Sclerotial initiation started on the $3^{\text {rd }}$ day after incubation at $30^{\circ} \mathrm{C}$ and $35^{\circ} \mathrm{C}$, and mature sclerotia were observed after 15 and 6 days of incubation, respectively. Optimal sclerotial production and the dry weight of 100 sclerotia varied depending on isolates and temperatures and occurred at $25^{\circ} \mathrm{C}-35^{\circ} \mathrm{C}$. No mature sclerotia were produced at $5^{\circ} \mathrm{C}, 10^{\circ} \mathrm{C}, 15^{\circ} \mathrm{C}$ and $40^{\circ} \mathrm{C}$. Sclerotial germination, noted after $24 \mathrm{~h}$ of incubation, was $96 \%-100 \%$ at $25^{\circ} \mathrm{C}-35^{\circ} \mathrm{C}$, declined at $15^{\circ} \mathrm{C}-20^{\circ} \mathrm{C}$, and was totally inhibited at $5^{\circ} \mathrm{C}, 10^{\circ} \mathrm{C}$ and $40^{\circ} \mathrm{C}$ even after $72 \mathrm{~h}$ of incubation. For all S. rolfsii isolates, optimal radial growth occurred on OAT medium followed by CZA, MYEA and PDA. When grown on PDA and OAT media, S. rolfsii developed cottony colonies with abundant mycelium whereas on WA and CZA pathogen growth was thin and scanty. Colonies formed on the other media developed sparse and flat mycelia. For sclerotial formation, WA and CZA were the most suitable culture media but no dark brown sclerotia were observed on NA and YDA. The highest sclerotial formation was observed on PDA and CZA. The highest sclerotium weight was produced by $\mathrm{Sr}^{3}$ isolate on PDA whereas for $\mathrm{Sr}^{1}$ and $\mathrm{Sr}^{2}$ isolates, sclerotial weights were significantly comparable on PDA, MYEA and CZA. Sclerotial germination was optimal on all tested media except NA. The significance of these findings on S. rolfsii biology is discussed.
\end{abstract}

Keywords: Culture media; Germination; Mycelial growth; Sclerotial production; Sclerotium rolfsii; Temperature

\section{Introduction}

The agricultural sector has an interesting impact gains in the economic development by contributing significantly to food security, national income and employment. However, despite this importance, agriculture faces multiple challenges especially the climate change, affecting negatively both crop and livestock systems with increases in temperatures, rainfall variation and the frequency and the intensity of extreme weather events [1]. Thus, because the environment significantly influences plants, pathogens and their antagonists, changes in environmental conditions are strongly associated with differences in the level of losses caused by a given disease, and environmental changes are often implicated in the emergence of new diseases [2]. Therefore, new, emerging, re-emerging and threatening plant diseases have been reported causing significant yield losses to several crops [3-6]. Among the re-emerging plant diseases, collar rot caused by Sclerotium rolfsii has become a major limiting factor and the challenging to both farmers and scientists. $S$. rolfsii is a soilborne fungal plant pathogen attacking an extensive host range, including more than 500 plant species $[7,8]$. It causes, during any plant growth stage, dark brown lesions on stems followed by drooping and wilting of leaves and gradually wilting of the whole plant. Such wilted plants show white cottony fungal thread girdling the basal part of stem and moving below stem to roots $[9,10]$. This pathogenic fungus is characterized by an abundant white mycelium and small-brown sclerotia developing on diseased tissue under hot humid conditions. Sclerotia serve as the principal over-wintering structure and primary inoculum for disease persistence near the soil surface [9]. This pathogen is responsible for heavy economic losses on many plant species. In fact, disease can cause dry-seed yield loss of up to $53.4 \%$ on cowpea [11]. In peppermint, this pathogen caused about $5 \%$ to $20 \%$ of crop loss under field conditions [12]. It is also considered as major threat to tomato and artichoke crops leading to $10 \%-45 \%$ [13] and $60 \%$ [14] plant losses, respectively. This fungus occurs worldwide but is more widespread throughout the most tropics and warmer regions of the temperate zones $[9,15]$. Therefore, environmental conditions may influence plant infection and consequently the levels of the induced losses [16]. In Tunisia, this pathogen was first reported on olive trees [17], on potato [18] and on apple trees [19]. Previous investigators studying the effects of environmental conditions indicated that optimal growth and sclerotial production and germination occurred at $25^{\circ} \mathrm{C}-30^{\circ} \mathrm{C}$ [20-23]. Nevertheless, Temperature variations may affect the shape and size of the sclerotia [9]. In fact, in California, this pathogen is most active at relatively warm temperatures $\left(27^{\circ} \mathrm{C}\right.$ to $\left.32^{\circ} \mathrm{C}\right)$ [24]. In Tunisia, the optimum growth occurred at $30^{\circ} \mathrm{C}-35^{\circ} \mathrm{C}$ [25]. The temperature requirements reflect its distribution and occurrence in warm regions of the world. Although previous investigations were 
Citation: Ayed F, Jabnoun-Khiareddine H, Aydi Ben Abdallah R, Daami-Remadi M (2018) Effect of Temperatures and Culture Media on Sclerotium rolfsii Mycelial Growth, Sclerotial Formation and Germination. J Plant Pathol Microbiol 9: 446. doi: $10.4172 / 2157-7471.1000446$

Page 2 of 9

focused on the influence of some abiotic factors on $S$. rolfsii, each of these studies concerned only a part of their biological cycle: mycelial growth or sclerotial production or sclerotial germination, separately. No previous studies examined all physiological parameters together nor investigated the relationship between environment conditions, pathogen mycelial growth and its sclerotial formation and production. Therefore, the objective of this study was to provide detailed information on the effects of temperature and culture media on mycelial growth, biomass production, sclerotial production and germination of three selected Tunisian $S$. rolfsii isolates. An understanding of the role of environmental conditions and their effects on pathogen development and survival is necessary to develop more effective management practices.

\section{Materials and Methods}

\section{Pathogen isolates}

Three $S$. rolfsii isolates were used in the current investigation. $\mathrm{Sr}^{2}$ and $\mathrm{Sr}^{3}$ were recovered from potato tubers showing severe soft rot symptoms and $\mathrm{Sr}^{1}$ was isolated from a rotted artichoke stem. These isolates were held in the laboratory of Phytopathology at the Regional Research Centre on Horticulture and Organic Agriculture of ChottMariem, Tunisia. Prior to use, isolates were grown on Potato Dextrose Agar (PDA) medium at $25^{\circ} \mathrm{C}$ in the dark.

\section{Effect of temperature on pathogen mycelial growth and sclerotial production and germination}

Effect on radial mycelial growth and sclerotial production: To examine the effect of temperature on the mycelial growth of three $S$. rolfsii isolates $\left(\mathrm{Sr}^{1}, \mathrm{Sr}^{2}\right.$ and $\left.\mathrm{Sr}^{3}\right)$, mycelial plugs $(6 \mathrm{~mm}$ in diameter) cut from the margin of 7-day-old growing colonies on PDA were placed in the centre of $90 \mathrm{~mm}$ Petri plates containing PDA medium amended with streptomycin sulfate $(300 \mathrm{mg} / \mathrm{L} \mathrm{w} / \mathrm{v})$. Inoculated plates were incubated in the dark at $5^{\circ} \mathrm{C}, 10^{\circ} \mathrm{C}, 15^{\circ} \mathrm{C}, 20^{\circ} \mathrm{C}, 25^{\circ} \mathrm{C}, 30^{\circ} \mathrm{C}, 35^{\circ} \mathrm{C}$, and $40^{\circ} \mathrm{C}$ for 3 days. The diameters of the resulting colonies were measured daily (after 24, 48 and $72 \mathrm{~h}$ of inoculation) and the radial growth rate $(\mathrm{mm} /$ day) was determined. The same Petri plates were further incubated at the tested temperatures for 21 days. After this incubation period, sclerotial formation and production were determined. Sclerotial formation was noted every 3 days [26]. Sclerotial production was determined by removing mature sclerotia with a sharp scalpel. Harvested sclerotia were placed in fine mesh nylon bags and washed thoroughly with Sterile Distilled Water (SDW) to remove agar debris. Washed sclerotia were counted and the average number of mature sclerotia produced per plate was determined. These sclerotia were placed on pre-dried and weighed Whatman $n^{\circ} 1$ filter papers and the dry weight of 100 sclerotia per plate was determined after $48 \mathrm{~h}$ of incubation at $70^{\circ} \mathrm{C}$. For all the parameters measured, ten replicate plates were used per individual treatment (per isolate and per temperature tested).

Effect on mycelium dry weight: In order to study the effect of temperature on mycelium dry weight, $15 \mathrm{ml}$ of Potato Dextrose Broth (PDB) medium contained in $150 \mathrm{ml}$-flasks was aseptically inoculated with 6-mm mycelial plugs cut from each $S$. rolfsii growing colony. Flasks were then incubated in the dark at the same temperatures tested above $\left(5^{\circ} \mathrm{C}-40^{\circ} \mathrm{C}\right)$. After 5 days of incubation, the resulting mycelial mat was filtered through Whatman $n^{\circ} 1$ filter paper, washed thoroughly with SDW, dried at $60^{\circ} \mathrm{C}$ for three days and weighed immediately on an analytical electrical balance. Ten replicates (flasks) were used per each individual treatment.

Effect on sclerotial germination: Similar-sized mature sclerotia (21day-old sclerotia) were used in this experiment. Ten sclerotia were placed onto $90 \mathrm{~mm}$-Petri plates containing PDA medium and incubated in the dark at the same temperatures tested above. Sclerotial germination was determined after 24,48 and $72 \mathrm{~h}$ of incubation by assessing individual sclerotia for outgrowing hyphae under a binocular microscope. A sclerotium was considered germinated when outgrowing hyphae were equal to or greater than its diameter. Ten replicate plates were used per each individual treatment and the percentage of germinated sclerotia per plate was recorded.

Effect of culture media on pathogen mycelial growth and sclerotial production and germination: The mycelial growth of $S$. rolfsii isolates as well as their sclerotial development, production and germination were evaluated on eight culture media: namely Potato Dextrose Agar (PDA), Sabouraud Chloramphenicol Agar (SAB), Czapek Dox Agar (CZA), Nutrient Agar (NA), Oat Meal Agar (OAT), Yeast Dextrose Agar (YDA), Malt Yeast Extract Agar (MYEA), and Water Agar (WA). All these media were prepared according to the manufacturer instructions (HiMedia, India), autoclaved at $121^{\circ} \mathrm{C}$ for $30 \mathrm{~min}$ and poured into Petri plates. Plates containing each of the eight tested media were inoculated with a 6-mm-mycelial plugs cut from a 7-dayold $S$. rolfsii colony previously grown on PDA and incubated at $30^{\circ} \mathrm{C}$. There were ten replicate plates for each individual treatment. The radial growth rate $(\mathrm{mm} /$ day), the sclerotial development, production and germination were evaluated as described above. Moreover, for all the three isolates tested, colony morphology was also examined and macro-morphologically characterized.

\section{Statistical analysis}

Statistical analyses were performed following a completely randomized factorial design where fungal treatments $(S$. rolfsii isolates) and tested factors (temperatures or culture media) were the two fixed independent variables. Ten replicates were used per each individual treatment and means were separated using Fisher's protected LSD or Students Neuman Keuls tests (at $\mathrm{p} \leq 0.05$ ). Statistical analyses were performed using SPSS software version 17. All the experiments were repeated twice and the mean data was presented in the current study.

\section{Results}

\section{Effect of temperature on $S$. rolfsii growth and survival}

Effect on radial mycelial growth: The rate of $S$. rolfsii mycelial growth, noted after 3 days of incubation on PDA, was significantly (at $\mathrm{p} \leq 0.05$ ) affected by temperatures tested and isolates used; a significant interaction was also noted between these two factors. As shown in Figure 1, all $S$. rolfsii isolates were able to grow over a range of temperatures varying from $10^{\circ} \mathrm{C}$ to $35^{\circ} \mathrm{C}$ whereas no growth was observed at $5^{\circ} \mathrm{C}$ and $40^{\circ} \mathrm{C}$. In general, the rate of mycelial growth increased as temperature increased up to $30^{\circ} \mathrm{C}$ and then decreased rapidly as temperature increased. At $10^{\circ} \mathrm{C}$, mycelial growth of all isolates was slow with an average rate of $3.31 \mathrm{~mm} /$ day, compared to significantly higher rates of $6.86,10.14,18.35$ and $15.80 \mathrm{~mm} /$ day, noted at $15^{\circ} \mathrm{C}, 20^{\circ} \mathrm{C}, 25^{\circ} \mathrm{C}$ and $35^{\circ} \mathrm{C}$, respectively. 
Citation: Ayed F, Jabnoun-Khiareddine H, Aydi Ben Abdallah R, Daami-Remadi M (2018) Effect of Temperatures and Culture Media on Sclerotium rolfsii Mycelial Growth, Sclerotial Formation and Germination. J Plant Pathol Microbiol 9: 446. doi: $10.4172 / 2157-7471.1000446$

Page 3 of 9

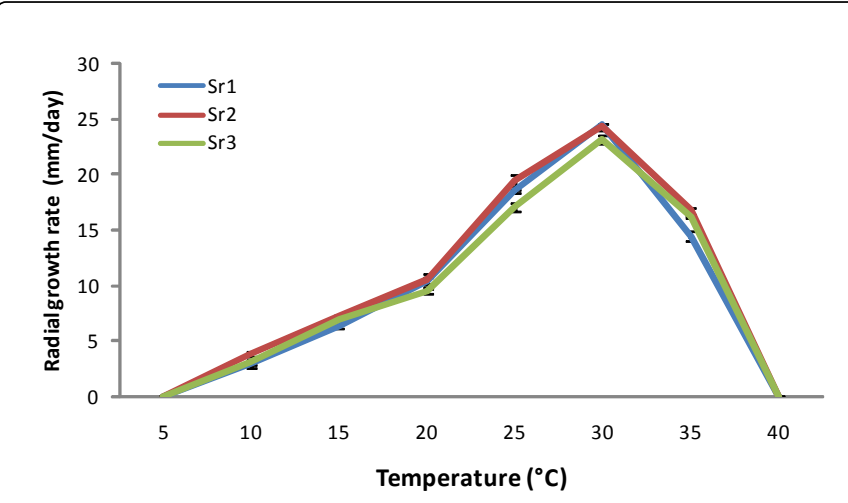

Figure 1: Effect of temperature on radial growth of three Sclerotium rolfsii isolates recorded after 3 days of incubation on PDA medium. LSD $($ Temperature $\times S$. rolfsii isolates $)=0.365 \mathrm{~mm}$ at $\mathrm{p} \leq 0.05$.

Optimum growth occurred at $30^{\circ} \mathrm{C}$ for all isolates, with an average growth of $24.04 \mathrm{~mm} /$ day. For pooled data of all tested temperatures, the radial mycelial growth of $\mathrm{Sr}^{2}$ isolate was significantly higher than that of $\mathrm{Sr}^{1}$ and $\mathrm{Sr}^{3}$.

Effect on mycelium dry weight: Growth of $S$. rolfsii in terms of mycelial dry weight, noted after 5 days of incubation on PDB medium, was significantly (at $\mathrm{p} \leq 0.05$ ) affected by temperatures tested. A significant interaction between temperatures and isolates was also noted. In general, mycelium dry weight increased as temperature increased up to $30^{\circ} \mathrm{C}$ and then decreased rapidly at higher temperatures tested (Figure 2). For all isolates, fungal biomass was optimum at $30^{\circ} \mathrm{C}$ with an average mycelial dry weight of $208 \mathrm{mg}$. These isolates showed also good growth at $25^{\circ} \mathrm{C}$. The mycelial growth of $\mathrm{Sr}^{2}$ isolate was significantly similar at $20^{\circ} \mathrm{C}$ and $35^{\circ} \mathrm{C}$, while that of $\mathrm{Sr}^{3}$ was better at $35^{\circ} \mathrm{C}$ than at $20^{\circ} \mathrm{C}$. The $\mathrm{Sr}^{1}$ isolate exhibited significantly comparable mycelial growth at 20 and $35^{\circ} \mathrm{C}$. Mycelial extension of $S$. rolfsii isolates was very restricted at $15^{\circ} \mathrm{C}$ and totally inhibited at $5^{\circ} \mathrm{C}$, $10^{\circ} \mathrm{C}$ and $40^{\circ} \mathrm{C}$ (Figure 2).

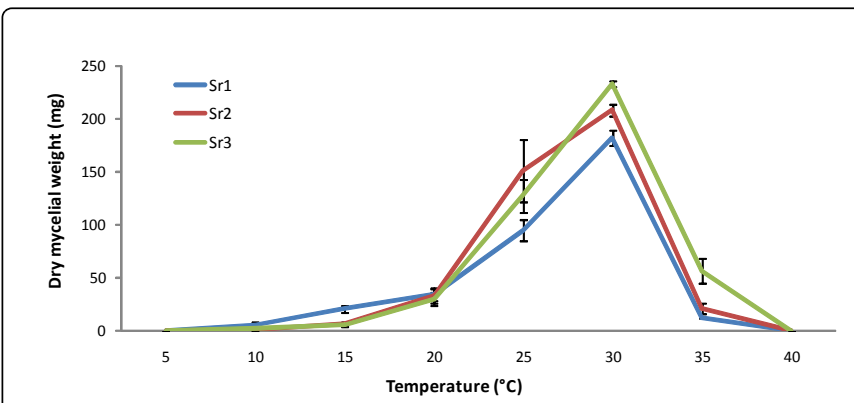

Figure 2: Effect of temperature on dry mycelial weight of three Sclerotium rolfsii isolates recorded after 5 days of incubation on $\mathrm{PDB}$ medium. LSD $($ Temperature $\times S$. rolfsii isolates $)=16.438 \mathrm{mg}$ at $\mathrm{p} \leq 0.05$.

Effect on sclerotial formation and production: As for the mycelial growth, sclerotial formation was affected by temperatures. As shown in Table 1, sclerotial initiation started on the $3^{\text {rd }}$ day after incubation at $30^{\circ} \mathrm{C}$ and $35^{\circ} \mathrm{C}$, as whitish, tiny, pinhead-like structures which became dark brown mature sclerotia after 15 and 6 days, respectively. At $10^{\circ} \mathrm{C}$ and $15^{\circ} \mathrm{C}-25^{\circ} \mathrm{C}$, sclerotial initiation was observed on the $9^{\text {th }}$ and $6^{\text {th }}$ days of incubation on PDA, respectively (Table 1).

\begin{tabular}{|c|c|c|c|c|}
\hline \multirow{2}{*}{$\begin{array}{l}\text { Temperature } \\
\left({ }^{\circ} \mathrm{C}\right)\end{array}$} & \multirow[t]{2}{*}{ Isolates } & \multicolumn{3}{|c|}{ Days after inoculation } \\
\hline & & $\begin{array}{l}\text { First } \\
\text { initials }\end{array}$ & $\begin{array}{l}\text { White } \\
\text { sclerotia }\end{array}$ & $\begin{array}{l}\text { Dark mature } \\
\text { sclerotia }\end{array}$ \\
\hline \multirow{3}{*}{5} & $\mathrm{Sr}^{1}$ & - & - & - \\
\hline & $\mathrm{Sr}^{2}$ & - & - & - \\
\hline & $\mathrm{Sr}^{3}$ & - & - & - \\
\hline \multirow{3}{*}{10} & $\mathrm{Sr}^{1}$ & 9 & - & - \\
\hline & $\mathrm{Sr}^{2}$ & 15 & - & - \\
\hline & $\mathrm{Sr}^{3}$ & 9 & - & - \\
\hline \multirow{3}{*}{15} & $\mathrm{Sr}^{1}$ & 6 & - & - \\
\hline & $\mathrm{Sr}^{2}$ & 6 & - & - \\
\hline & $\mathrm{Sr}^{3}$ & 6 & 21 & - \\
\hline \multirow{3}{*}{20} & $\mathrm{Sr}^{1}$ & 6 & 15 & 18 \\
\hline & $\mathrm{Sr}^{2}$ & 6 & 18 & 21 \\
\hline & $\mathrm{Sr}^{3}$ & 6 & 18 & 21 \\
\hline \multirow{3}{*}{25} & $\mathrm{Sr}^{1}$ & 6 & 12 & 15 \\
\hline & $\mathrm{Sr}^{2}$ & 6 & 12 & 15 \\
\hline & $\mathrm{Sr}^{3}$ & 6 & 12 & 15 \\
\hline \multirow{3}{*}{30} & $\mathrm{Sr}^{1}$ & 3 & 9 & 15 \\
\hline & $\mathrm{Sr}^{2}$ & 3 & 9 & 15 \\
\hline & $\mathrm{Sr}^{3}$ & 3 & 9 & 12 \\
\hline \multirow{3}{*}{35} & $\mathrm{Sr}^{1}$ & 3 & 4 & 6 \\
\hline & $\mathrm{Sr}^{2}$ & 3 & 4 & 6 \\
\hline & $\mathrm{Sr}^{3}$ & 3 & 4 & 6 \\
\hline \multirow{3}{*}{40} & $\mathrm{Sr}^{1}$ & - & - & - \\
\hline & $\mathrm{Sr}^{2}$ & - & - & - \\
\hline & $\mathrm{Sr}^{3}$ & - & - & - \\
\hline
\end{tabular}

Table 1: Effect of temperature on sclerotial development of three Sclerotium rolfsii isolates on PDA medium noted after 21 days of incubation in the dark.

For all $S$. rolfsii isolates, sclerotial formation was relatively very slow at $10^{\circ} \mathrm{C}-15^{\circ} \mathrm{C}$ and no mature sclerotia were produced even after 21 days of incubation. At $5^{\circ} \mathrm{C}$ and $40^{\circ} \mathrm{C}$, there was no sclerotium formation for all isolates till 21 days of culture (Table 1). The average number of mature sclerotia, produced per plate after 21 days of incubation on PDA medium, varied significantly (at $\mathrm{p} \leq 0.05$ ) depending on tested temperatures and $S$. rolfsii isolates and their interactions. As given in Table 2. $\mathrm{Sr}^{1}$ isolate showed optimal sclerotial production at $25^{\circ} \mathrm{C}$, estimated at 228.6 sclerotia/plate, which was significantly reduced when temperature increased up to 30 and $35^{\circ} \mathrm{C}$. 
Citation: Ayed F, Jabnoun-Khiareddine H, Aydi Ben Abdallah R, Daami-Remadi M (2018) Effect of Temperatures and Culture Media on Sclerotium rolfsii Mycelial Growth, Sclerotial Formation and Germination. J Plant Pathol Microbiol 9: 446. doi: $10.4172 / 2157-7471.1000446$

Page 4 of 9

For $\mathrm{Sr}^{2}$, sclerotial yield was significantly similar at $25^{\circ} \mathrm{C}-35^{\circ} \mathrm{C}$ with an average of 131 and 156.4 mature sclerotia/plate, respectively. When grown at $35^{\circ} \mathrm{C}, \mathrm{Sr}^{3}$ showed its maximum sclerotial production, of about 290.8 sclerotia/plate, which was significantly 4 times higher than that recorded at $30^{\circ} \mathrm{C}$ and $25^{\circ} \mathrm{C}$. After 21 days of incubation at $20^{\circ} \mathrm{C}$, all $S$. rolfsii isolates produced very few and scattered mature sclerotia. However, no mature sclerotia were produced at $5^{\circ} \mathrm{C}, 10^{\circ} \mathrm{C}, 15^{\circ} \mathrm{C}$ and $40^{\circ} \mathrm{C}$.

\begin{tabular}{|c|c|c|c|c|}
\hline \multirow[t]{2}{*}{ Temperature $^{\mathrm{a}}\left({ }^{\circ} \mathrm{C}\right)$} & \multicolumn{3}{|c|}{$\begin{array}{l}\text { Number of sclerotia per } \\
\text { plate }\end{array}$} & \multirow[t]{2}{*}{$\begin{array}{l}\text { Mean number of } \\
\text { sclerotia per } \\
\text { temperature }\end{array}$} \\
\hline & $\mathrm{Sr}^{1}$ & $\mathrm{Sr}^{2}$ & $\mathrm{Sr}^{3}$ & \\
\hline 5 & $0^{c}$ & $0^{d}$ & $0^{c}$ & $0^{c}$ \\
\hline 10 & $0^{c}$ & $0^{\mathrm{d}}$ & $0^{c}$ & $0^{c}$ \\
\hline 15 & $0^{c}$ & $0^{\mathrm{d}}$ & $0^{c}$ & $0^{c}$ \\
\hline 20 & $22.2^{\mathrm{c}}$ & $10^{d}$ & $7.6^{\mathrm{c}}$ & $13.27^{\mathrm{c}}$ \\
\hline 25 & $228.6^{\mathrm{a}}$ & $131^{\mathrm{c}}$ & $71.8^{\mathrm{b}}$ & $143.8^{\mathrm{b}}$ \\
\hline 30 & $147.8^{b}$ & $189.6^{\mathrm{a}}$ & $73^{b}$ & $136 .^{\mathrm{b}}$ \\
\hline 35 & $154^{b}$ & $156.4^{\mathrm{bc}}$ & $290.8^{a}$ & $200.4^{a}$ \\
\hline 40 & $0^{\mathrm{c}}$ & $0^{d}$ & $0^{c}$ & $0^{c}$ \\
\hline $\begin{array}{l}\text { Mean number of } \\
\text { sclerotia per isolate }^{c}\end{array}$ & $69.07^{\mathrm{a}}$ & $60.87^{a b}$ & $55.4^{\mathrm{b}}$ & - \\
\hline \multicolumn{5}{|c|}{ a Temperatures $\left(5,10,15,20,25,30,35\right.$, and $\left.40^{\circ} \mathrm{C}\right)$} \\
\hline \multicolumn{5}{|c|}{${ }^{\mathrm{b}}$ Mean number of sclerotia per temperature for the three isolates combined } \\
\hline \multicolumn{5}{|c|}{${ }^{\mathrm{C}}$ Mean number of sclerotia per isolate for all tested temperatures } \\
\hline \multicolumn{5}{|c|}{${ }^{*}$ LSD $($ Temperature $\times$ S. rolfsii isolates $)=26.774$ sclerotia at $p \leq 0.05$} \\
\hline \multicolumn{5}{|c|}{$\begin{array}{l}\text { "For the number of sclerotia of each isolate and for their mean per temperature, } \\
\text { values followed by the same letter are not significantly different according to } \\
\text { Duncan Multiple Range test (at } p \leq 0.05 \text { ) }\end{array}$} \\
\hline
\end{tabular}

Table 2: Effect of temperature on the number of sclerotia produced by three Sclerotium rolfsii isolates on PDA medium after 21 days of incubation in the dark.

The dry weight of 100 sclerotia, formed after 21 days of incubation on PDA, varied significantly (at $\mathrm{p} \leq 0.05$ ) depending on isolates used and temperatures tested; a significant interaction was also noted between both fixed factors. As shown in Table 3, the highest dry weight of 100 sclerotia was recorded at $25^{\circ} \mathrm{C}$ and $30^{\circ} \mathrm{C}$ for $S$. rolfsii isolates $\mathrm{Sr}^{1}$ and $\mathrm{Sr}^{3}$ and decreased at $35^{\circ} \mathrm{C}$. However, for $\mathrm{Sr}^{2}$, the dry weight of 100 sclerotia was significantly higher at $25^{\circ} \mathrm{C}$ than at 30 and $35^{\circ} \mathrm{C}$. Based on pooled data of all the temperatures, the dry weight of 100 sclerotia produced by $\mathrm{Sr}^{3}$ isolate, after incubation for 21 days on PDA, was significantly higher than that of the two other isolates (Table 3).

\begin{tabular}{|l|l|l|l|l|}
\hline \multirow{2}{*}{$\begin{array}{l}\text { Temperature } \\
\left({ }^{\circ} \mathrm{C}\right)\end{array}$} & \multicolumn{2}{|l|}{$\begin{array}{l}\text { Dry weight of } 100 \text { sclerotia } \\
(\mathbf{m g})\end{array}$} & $\begin{array}{l}\text { Mean dry weight per } \\
\text { temperature }\end{array}$ \\
\cline { 2 - 4 } & $\mathrm{Sr}^{\mathrm{b}}$ & $\mathrm{Sr}^{2}$ & $\mathrm{Sr}^{3}$ & \\
\hline 25 & $47.93^{\mathrm{a}}$ & $55.33^{\mathrm{a}}$ & $80.34^{\mathrm{a}}$ & $61.2^{\mathrm{a}}$ \\
\hline 30 & $47.01^{\mathrm{a}}$ & $36.08^{\mathrm{b}}$ & $74.38^{\mathrm{a}}$ & $52.48^{\mathrm{b}}$ \\
\hline 35 & $28.61^{\mathrm{b}}$ & $20.83^{\mathrm{c}}$ & $34.22^{\mathrm{b}}$ & $27.89^{\mathrm{c}}$ \\
\hline
\end{tabular}

\begin{tabular}{|l|l|l|l|}
\hline $\begin{array}{l}\text { Mean dry weight } 41.18^{\mathrm{b}} \\
\text { per isolate }\end{array}$ & $37.41^{\mathrm{b}}$ & $62.98^{\mathrm{a}}$ & - \\
\hline a Temperatures $\left(25,30\right.$ and $\left.35^{\circ} \mathrm{C}\right)$ \\
b Mean dry weight of 100 sclerotia per temperature for the three isolates \\
combined \\
${ }^{\mathrm{C}}$ Mean dry weight of 100 sclerotia per isolate for all tested temperatures \\
${ }^{*}$ LSD (Temperature $\times S$. rolfsii isolates) $=6.713 \mathrm{mg}$ at $\mathrm{p} \leq 0.05$ \\
${ }^{*}$ For the dry weight of 100 sclerotia of each isolate and for their mean per \\
temperature, values followed by the same letter are not significantly different \\
according to Duncan Multiple Range test (at $\mathrm{p} \leq 0.05)$.
\end{tabular}

Table 3: Effect of temperature on the dry weight of 100 sclerotia of three Sclerotium rolfsii isolates formed on PDA medium after 21 days of incubation in the dark.

Effect on sclerotial germination: The germination of $S$. rolfsii sclerotia, recorded after $24 \mathrm{~h}$ of incubation on PDA, varied significantly (at $\mathrm{p} \leq 0.05$ ) depending on tested temperatures and $S$. rolfsii isolates as well as their interaction (Figure 3 ).

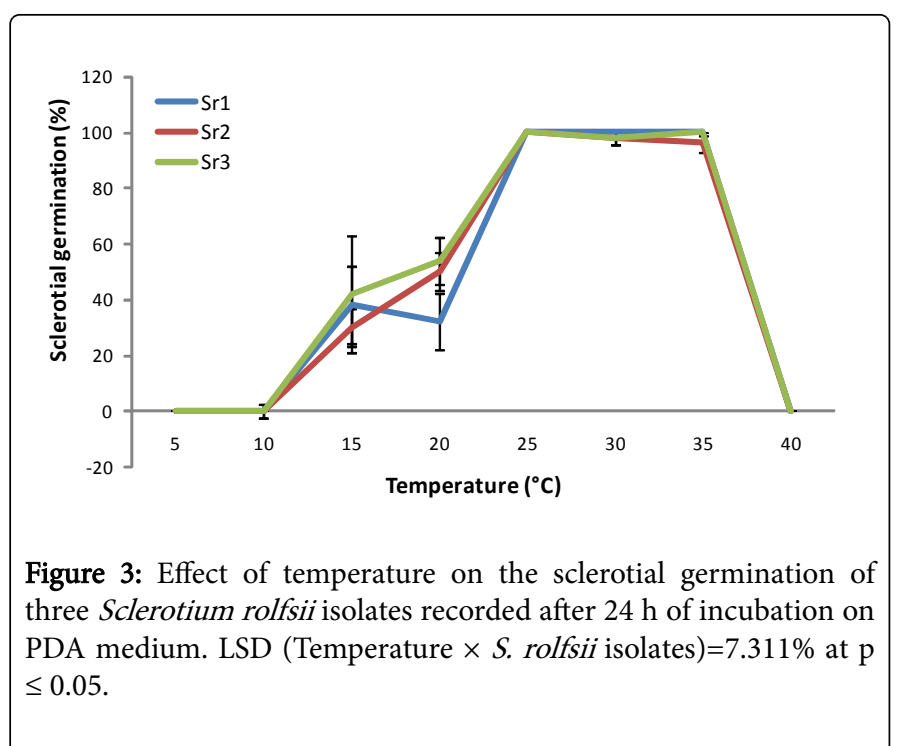

The optimum temperature range for sclerotial germination was fixed at $25-35^{\circ} \mathrm{C}$ for all isolates tested. The percentage of sclerotial germination was $62 \%-68 \%, 49 \%-70 \%$, and $46 \%-58 \%$ lower at $20^{\circ} \mathrm{C}$ and $15^{\circ} \mathrm{C}$, for $\mathrm{Sr}^{1}, \mathrm{Sr}^{2}$ and $\mathrm{Sr}^{3}$, respectively, and reached $100 \%$ after $72 \mathrm{~h}$ of incubation (data not shown). Sclerotial germination was inhibited at $5^{\circ} \mathrm{C}, 10^{\circ} \mathrm{C}$ and $40^{\circ} \mathrm{C}$, even after $72 \mathrm{~h}$ of incubation.

\section{Effect of culture media on $\boldsymbol{S}$. rolfsii growth and survival}

Effect on radial mycelial growth: $S$. rolfsii isolates were able to grow on all tested culture media. However, the rate of their radial growth, recorded after 3 days of incubation at $30^{\circ} \mathrm{C}$, varied significantly (at $\mathrm{p} \leq$ 0.05 ) depending on tested isolates and culture media. A significant interaction was also noted between both fixed variables. For all $S$. rolfsii isolates, optimal radial growth occurred on OAT medium followed by CZA, MYEA and PDA (Table 4). SAB and YDA supported also good radial growth of all isolates. The poorest mycelial growth was recorded on NA for $\mathrm{Sr}^{1}$ and $\mathrm{Sr}^{2}$ isolates and on NA and WA for $\mathrm{Sr}^{3}$ (Table 4). Regardless the tested culture medium (pooled data of all media), $\mathrm{Sr}^{2}$ was the fastest growing isolate. For all $S$. rolfsii isolates, 
Citation: Ayed F, Jabnoun-Khiareddine H, Aydi Ben Abdallah R, Daami-Remadi M (2018) Effect of Temperatures and Culture Media on Sclerotium rolfsii Mycelial Growth, Sclerotial Formation and Germination. J Plant Pathol Microbiol 9: 446. doi: 10.4172/2157-7471.1000446

Page 5 of 9

morphological differences were detected among colonies, formed after 3 days of incubation at $30^{\circ} \mathrm{C}$, on the different culture media (Table 4). When grown on PDA and OAT, $S$. rolfsii developed cottony colonies with abundant mycelium whereas on WA and CZA growth was thin and scanty. Colonies formed on the other media (SAB, MYEA, YDA and NA) developed sparse and flat mycelia (Table 4 and Figure 4).

\begin{tabular}{|c|c|c|c|c|c|c|c|}
\hline \multirow[t]{2}{*}{ Tested media ${ }^{a}$} & \multicolumn{4}{|c|}{ Mycelial growth (mm/day) } & \multicolumn{3}{|c|}{ Mycelial growth characteristics } \\
\hline & $\mathrm{Sr}^{1}$ & $\mathrm{Sr}^{2}$ & $\mathrm{Sr}^{3}$ & $\begin{array}{l}\text { Mean mycelial } \\
\text { growth } \\
\text { per medium }^{b}\end{array}$ & Mycelial density & Colony shape & Mycelial texture \\
\hline PDA & $24.4^{b}$ & $23.99^{c}$ & $22.93 \mathrm{bc}$ & $23.77^{c}$ & Abundant & Regular & Cottony \\
\hline OAT & $28.04^{a}$ & $28.52^{a}$ & $27.15^{a}$ & $27.91^{a}$ & Abundant & Regular & Cottony \\
\hline MYEA & $24.97^{b}$ & $25.59^{b}$ & $23.43 \mathrm{bc}$ & $25.07^{b}$ & Moderate to abundant & Regular & Semi-cottony \\
\hline CZA & $24.94^{b}$ & $25.19^{b}$ & $24.64^{b}$ & $24.52^{b}$ & Poor & Irregular & Flat to semi-cottony \\
\hline WA & $21.52^{d}$ & $23.11^{d}$ & 17.74 de & $20.79^{e}$ & Extremely poor & Regular & Flat \\
\hline$S A B$ & $22.14^{\mathrm{c}}$ & $21.79^{e}$ & $21.47^{c}$ & $21.8^{d}$ & Moderate to abundant & Regular & Semi-cottony \\
\hline YDA & $19.61^{\mathrm{e}}$ & $20.77^{f}$ & $18.78^{d}$ & $19.72^{f}$ & Moderate & Regular & Flat to semi-cottony \\
\hline NA & $15.92^{f}$ & $17.82 \mathrm{~g}$ & $16.59^{e}$ & $16.78^{\mathrm{g}}$ & Moderate & Regular & Flat to semi-cottony \\
\hline $\begin{array}{lr}\text { Mean } & \text { mycelial } \\
\text { growth } & \text { per } \\
\text { isolate }^{c} & \end{array}$ & $22.69^{b}$ & $23.35^{a}$ & $21.59^{c}$ & & & & \\
\hline $\begin{array}{l}\text { a PDA: Potato De } \\
\text { YDA: Yeast Dextr } \\
{ }^{b} \text { Mean radial my } \\
{ }^{c} \text { Mean radial my } \\
{ }^{*} \text { LSD (Culture me }\end{array}$ & $\begin{array}{l}\text { xtrose } \mathrm{Ag} \\
\text { rose Agar; } \\
\text { celial gron } \\
\text { celial gron } \\
\text { dia } \times \text { S. } r\end{array}$ & $\begin{array}{l}\mathrm{T} \text { : Oatme } \\
\text { Jutrient } \mathrm{Ag} \\
\text { medium } \mathrm{f} \\
\text { isolate for } \\
\text { olates) }=0\end{array}$ & $\begin{array}{l}\text {; MYEA: M } \\
\text { three isolat } \\
\text { edia combir } \\
\mathrm{nm} \text { at } \mathrm{p} \leq 0\end{array}$ & $\begin{array}{l}\text { least Extract Agar } \\
\text { ombined }\end{array}$ & Czapek dox Agar; WA: V & ater Agar; SAB: $\mathrm{S}$ & aud Chloramphenicol \\
\hline
\end{tabular}

Table 4: Radial mycelial growth and characteristics of three Sclerotium rolfsii isolates noted on eight culture media after 3 days of incubation at $30^{\circ} \mathrm{C}$.

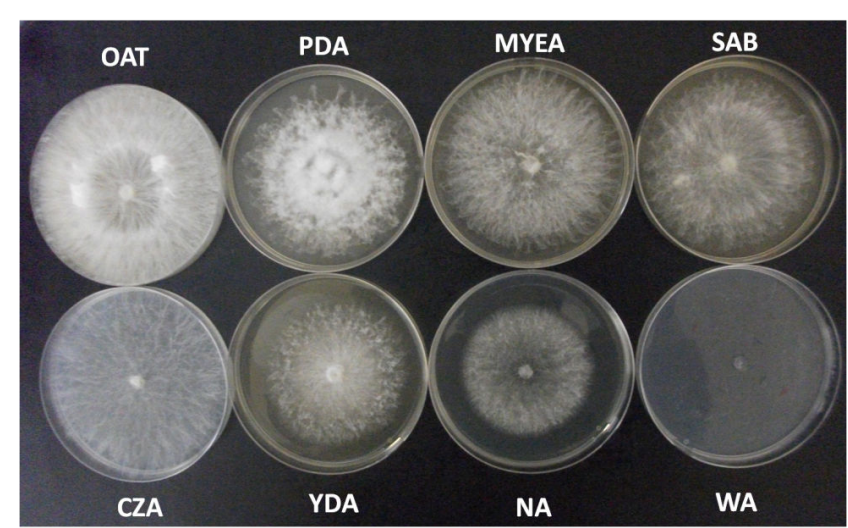

Figure 4: Colonies of Sclerotium rolfsii isolate $\mathrm{Sr}^{1}$ formed after 3 days of incubation at $30^{\circ} \mathrm{C}$ on different agar media. Note: PDA: Potato Dextrose Agar; SAB: Sabouraud Chloramphenicol Agar; CZA: Czapek Dox Agar; NA: Nutrient Agar; OAT: Oatmeal Agar; YDA: Yeast Dextrose Agar; MYEA: Malt Yeast Extract Agar; WA: Water Agar.
Effect on sclerotial formation and production: As indicated in Table 6, WA and CZA were the most suitable culture media for $S$. rolfsii sclerotial formation as mature sclerotia became brownish at the $9^{\text {th }}$ and $9-12^{\text {th }}$ day of incubation, respectively. However, sclerotial development was found to be very slow on NA and YDA and no dark brown sclerotia were observed even after 21 days of incubation. On the other media, such as PDA and MYEA, brown mature sclerotia were observed only after 12-15 and 15-21 days, respectively (Table 6). Sclerotial formation varied also among isolates. Indeed, for $\mathrm{Sr}^{2}$ and $\mathrm{Sr}^{3}$ isolates, sclerotial initiation was observed after 6 to 9 days of incubation on $\mathrm{OAT}$ and $\mathrm{SAB}$ and no mature sclerotia were formed even after 21 days, while for $\mathrm{Sr}^{1}$ isolate dark brown sclerotia were produced at $15^{\text {th }}$ day on both media (Table 6). The average number of mature sclerotia, produced per plate after 21 days of incubation, varied significantly (at $\mathrm{p} \leq 0.05)$ depending on media and isolates tested. A significant interaction was noted between these two factors. As indicated in Table 5 , the highest sclerotial yields were produced by $\mathrm{Sr}^{1}$ and $\mathrm{Sr}^{2}$ isolates on $\mathrm{PDA}$, followed by CZA, while $\mathrm{Sr}^{3}$ formed significantly more sclerotia on CZA followed by PDA. When grown on SAB and OAT media, only $\mathrm{Sr}^{1}$ produced mature sclerotia. All $S$. rolfsii isolates produced fewer sclerotia when grown on WA and NA whereas YDA did not support any sclerotial formation (Table 5). For all culture media combined (pooled data of all media), $\mathrm{Sr}^{1}$ and $\mathrm{Sr}^{2}$ isolates produced significantly more sclerotia than $\mathrm{Sr}^{3}$ isolate. 
Citation: Ayed F, Jabnoun-Khiareddine H, Aydi Ben Abdallah R, Daami-Remadi M (2018) Effect of Temperatures and Culture Media on Sclerotium rolfsii Mycelial Growth, Sclerotial Formation and Germination. J Plant Pathol Microbiol 9: 446. doi: $10.4172 / 2157-7471.1000446$

Page 6 of 9

\begin{tabular}{|c|c|c|c|c|}
\hline \multirow[t]{2}{*}{ Tested mediaa } & \multicolumn{3}{|c|}{ Number of sclerotia per plate } & \multirow[t]{2}{*}{ Mean number of sclerotia per medium ${ }^{b}$} \\
\hline & $\mathrm{Sr}^{1}$ & $\mathrm{Sr}^{2}$ & $\mathrm{Sr}^{3}$ & \\
\hline PDA & $147.8^{\text {a }}$ & $189.61^{a}$ & $73^{b}$ & $136.8^{\text {a }}$ \\
\hline OAT & $50.4 \mathrm{~cd}$ & $0^{d}$ & $0^{d}$ & $16.8^{d}$ \\
\hline MYEA & $57.7^{\mathrm{cd}}$ & $70.2^{c}$ & $45.2^{c}$ & $57.7^{\mathrm{c}}$ \\
\hline CZA & $131.6^{\mathrm{b}}$ & $105.6^{b}$ & $108.5^{a}$ & $115.23^{b}$ \\
\hline WA & $2.3^{d}$ & $2.5^{d}$ & $2.2^{d}$ & $2.33^{d}$ \\
\hline SAB & $77.5^{\mathrm{c}}$ & $0^{d}$ & $0^{d}$ & $25.83^{d}$ \\
\hline YDA & $0^{d}$ & $0^{d}$ & $0^{d}$ & $0^{d}$ \\
\hline NA & $0.9^{d}$ & $1.2^{d}$ & $0^{d}$ & $0.7^{d}$ \\
\hline Mean number of sclerotia produced per isolate ${ }^{c}$ & $58.67^{a}$ & $46.14^{a}$ & $28.61^{b}$ & - \\
\hline \multicolumn{5}{|c|}{$\begin{array}{l}\text { a PDA: Potato Dextrose Agar; OAT: Oatmeal Agar; MYEA: Malt Yeast Extract Agar; CZA: Czapek dox Agar; WA: Water Agar; SAB: Sabouraud Chloramphenicol Agar } \\
\text { YDA: Yeast Dextrose Agar; NA: Nutrient Agar. }\end{array}$} \\
\hline \multicolumn{5}{|c|}{ b Mean number of sclerotia per medium for the three isolates combined } \\
\hline \multicolumn{5}{|c|}{${ }^{\mathrm{C}}$ Mean number of sclerotia per isolate for all media combined } \\
\hline \multicolumn{5}{|c|}{ *LSD (Culture media $\times$ S. rolfsii isolates $)=30.123$ sclerotia at $p \leq 0.05$} \\
\hline \multicolumn{5}{|c|}{$\begin{array}{l}\text { "For the number of sclerotia of each isolate and for their mean per medium, values followed by the same letter are not significantly different according to Duncan } \\
\text { Multiple Range test (at } p \leq 0.05 \text { ). }\end{array}$} \\
\hline
\end{tabular}

Table 5: Sclerotial production of three Sclerotium rolfsii isolates on eight culture media noted after 21 days of incubation at $30^{\circ} \mathrm{C}$.

Among the eight culture media tested for sclerotial production, PDA, CZA and MYEA were assessed for their effect on sclerotial dry weight. The dry weight of 100 sclerotia, produced per plate, was significantly (at $\mathrm{p} \leq 0.05$ ) affected by culture media, isolates and their interactions (Table 7).

\begin{tabular}{|c|c|c|c|c|}
\hline \multirow[t]{2}{*}{ Medium* } & \multirow[t]{2}{*}{ Isolates } & \multicolumn{3}{|c|}{ Days after inoculation } \\
\hline & & First initials & $\begin{array}{l}\text { White } \\
\text { sclerotia }\end{array}$ & $\begin{array}{l}\text { Dark } \\
\text { mature } \\
\text { sclerotia }\end{array}$ \\
\hline \multirow[t]{3}{*}{ PDA } & $\mathrm{Sr}^{1}$ & 3 & 9 & 15 \\
\hline & $\mathrm{Sr}^{2}$ & 3 & 9 & 15 \\
\hline & $\mathrm{Sr}^{3}$ & 3 & 9 & 12 \\
\hline \multirow[t]{3}{*}{ OAT } & $\mathrm{Sr}^{1}$ & 3 & 9 & 15 \\
\hline & $\mathrm{Sr}^{2}$ & 6 & 21 & - \\
\hline & $\mathrm{Sr}^{3}$ & 6 & 21 & - \\
\hline \multirow[t]{3}{*}{ MYEA } & $\mathrm{Sr}^{1}$ & 6 & 12 & 18 \\
\hline & $\mathrm{Sr}^{2}$ & 6 & 12 & 15 \\
\hline & $\mathrm{Sr}^{3}$ & 9 & 15 & 21 \\
\hline \multirow[t]{3}{*}{$\mathrm{CZA}$} & $\mathrm{Sr}^{1}$ & 3 & 6 & 9 \\
\hline & $\mathrm{Sr}^{2}$ & 3 & 9 & 12 \\
\hline & $\mathrm{Sr}^{3}$ & 3 & 9 & 12 \\
\hline WA & $\mathrm{Sr}^{1}$ & - & - & 9 \\
\hline
\end{tabular}

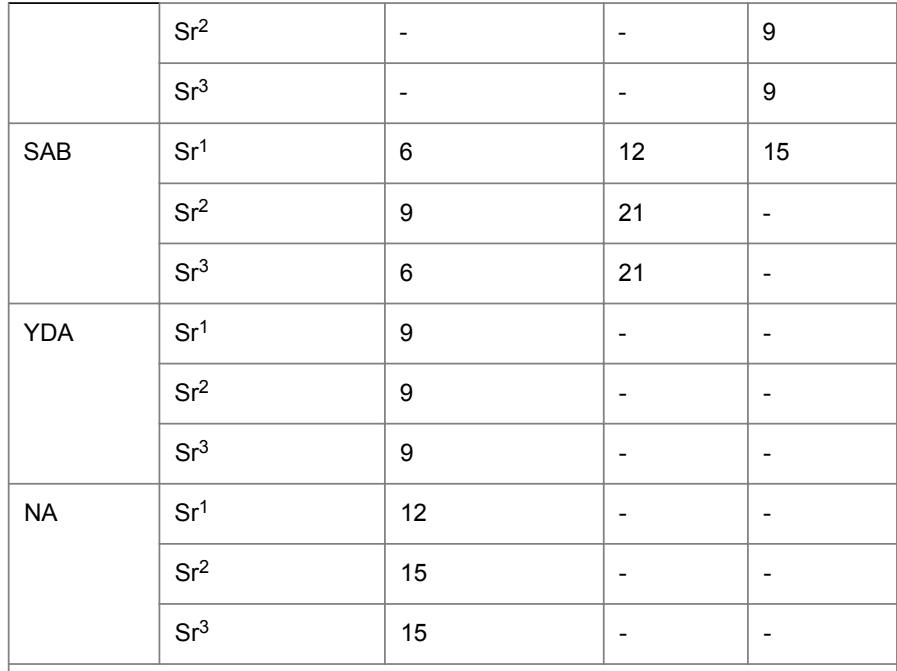

"PDA: Potato Dextrose Agar; OAT: Oatmeal Agar; MYEA: Malt Yeast Extract Agar; CZA: Czapek dox Agar; WA: Water Agar; SAB: Sabouraud Chloramphenicol Agar; YDA: Yeast Dextrose Agar; NA: Nutrient Agar.

Table 6: Effect of culture media on sclerotial development of three Sclerotium rolfsii isolates noted till 21 days of incubation at $30^{\circ} \mathrm{C}$ on PDA medium and in the dark.

In fact, the dry weight of 100 sclerotia produced by $\mathrm{Sr}^{3}$ isolate was highest on PDA than on CZA and MYEA, whereas both $\mathrm{Sr}^{1}$ and $\mathrm{Sr}^{2}$ isolates showed significantly comparable sclerotial dry weights on the three media. Moreover, for the pooled data of all three culture media, the maximum dry weight of 100 sclerotia was produced by $\mathrm{Sr}^{3}$ isolate (Table 7). 
Citation: Ayed F, Jabnoun-Khiareddine H, Aydi Ben Abdallah R, Daami-Remadi M (2018) Effect of Temperatures and Culture Media on Sclerotium rolfsii Mycelial Growth, Sclerotial Formation and Germination. J Plant Pathol Microbiol 9: 446. doi: $10.4172 / 2157-7471.1000446$

Page 7 of 9

\begin{tabular}{|l|l|l|l|l|}
\hline \multirow{2}{*}{$\begin{array}{l}\text { Tested } \\
\text { media }\end{array}$} & \multicolumn{2}{|l|}{$\begin{array}{l}\text { Dry weight of } 100 \text { sclerotia } \\
\text { (mg) }\end{array}$} & $\begin{array}{l}\text { Mean dry weight per } \\
\text { medium }\end{array}$ \\
\cline { 2 - 4 } & $\mathbf{S r}^{\mathrm{b}}$ & $\mathbf{S r}^{2}$ & $\mathbf{S r}^{3}$ & \\
\hline PDA & $47^{\mathrm{a}}$ & $36.08^{\mathrm{a}}$ & $74.37^{\mathrm{a}}$ & $52.48^{\mathrm{a}}$ \\
\hline MYEA & $37.52^{\mathrm{a}}$ & $41.2^{\mathrm{a}}$ & $42.91^{\mathrm{c}}$ & $40.56^{\mathrm{b}}$ \\
\hline CZA & $51^{\mathrm{a}}$ & $45.87^{\mathrm{a}}$ & $56.46^{\mathrm{b}}$ & $51.11^{\mathrm{a}}$ \\
\hline $\begin{array}{l}\text { Mean dry } \\
\text { weight } \\
\text { isolate }\end{array}$ & $45.17^{\mathrm{b}}$ & $41.07^{\mathrm{b}}$ & $57.91^{\mathrm{a}}$ & - \\
\hline per & & & & \\
\hline
\end{tabular}

a PDA: Potato Dextrose Agar; MYEA: Malt Yeast Extract Agar; CZA: Czapek dox Agar.

b Mean dry weight of 100 sclerotia per medium for the three isolates combined

c Mean dry weight of 100 sclerotia per isolate for all media combined

${ }^{*}$ LSD (Culture media $\times S$. rolfsii isolates $)=8.804 \mathrm{mg}$ at $\mathrm{p} \leq 0.05$

${ }^{*}$ For the dry weight of 100 sclerotia of each isolate and for their mean per medium, values followed by the same letter are not significantly different according to Duncan Multiple Range test (at $p \leq 0.05$ ).

Table 7: Dry weight of 100 sclerotia of three Sclerotium rolfsii isolates produced on three culture media after 21 days of incubation at $30^{\circ} \mathrm{C}$.

Effect on sclerotial germination: The germination of $S$. rolfsii sclerotia, noted after $24 \mathrm{~h}$ of incubation at $30^{\circ} \mathrm{C}$, occurred on all culture media tested and varied significantly (at $\mathrm{p} \leq 0.05$ ) depending on isolates used and culture media tested. A significant interaction was also noted between both fixed factors. In fact, as indicated in Table 8, optimal germination was recorded on PDA and MYEA media, followed by YDA, for $\mathrm{Sr}^{1}$ isolate, while that of $\mathrm{Sr}^{2}$ was noted on OAT and YDA, followed by MYEA, SAB, and WA. PDA, MYEA, OAT, followed by CZA, WA, and YDA were the most favorable media for the germination of $\mathrm{Sr}^{3}$ sclerotia. For all isolates tested, the lowest sclerotial germination rate was observed on NA (Table 8).

\begin{tabular}{|c|c|c|c|c|}
\hline \multirow[t]{2}{*}{ Tested media ${ }^{a}$} & \multicolumn{3}{|c|}{ Sclerotial germination (\%) } & \multirow{2}{*}{$\begin{array}{l}\text { Mean sclerotial } \\
\text { germination per } \\
\text { medium }^{b}\end{array}$} \\
\hline & $\mathrm{Sr}^{1}$ & $\mathrm{Sr}^{2}$ & $\mathrm{Sr}^{3}$ & \\
\hline PDA & $100^{a}$ & $88^{b}$ & $100^{a}$ & $96 \mathrm{ab}$ \\
\hline OAT & $90 \mathrm{bc}$ & $100^{a}$ & $100^{a}$ & 96.67 ab \\
\hline MYEA & $100^{a}$ & $90 \mathrm{ab}$ & $100^{a}$ & $96.67 \mathrm{ab}$ \\
\hline CZA & $90 \mathrm{bc}$ & $96^{a b}$ & $98^{a b}$ & $94.67^{a b}$ \\
\hline WA & $84^{c}$ & $94^{a b}$ & $96^{a b}$ & $91.33^{b}$ \\
\hline SAB & $90 \mathrm{bc}$ & $94^{a b}$ & $92^{\mathrm{b}}$ & $92^{b}$ \\
\hline YDA & $96 \mathrm{ab}$ & $100^{a}$ & $98^{a b}$ & $98^{a}$ \\
\hline NA & $8^{d}$ & $12^{c}$ & $22^{c}$ & $14^{\mathrm{c}}$ \\
\hline $\begin{array}{lr}\text { Mean } & \text { sclerotial } \\
\text { number } & \text { per } \\
\text { isolate }^{\mathrm{C}} & \end{array}$ & $82.25^{b}$ & $84.25^{b}$ & $88.25^{a}$ & - \\
\hline \multicolumn{5}{|c|}{$\begin{array}{l}\text { a PDA: Potato Dextrose Agar; OAT: Oatmeal Agar; MYEA: Malt Yeast } \\
\text { Agar; CZA: Czapek dox Agar; WA: Water Agar; SAB: Sabc } \\
\text { Chloramphenicol Agar; YDA: Yeast Dextrose Agar; NA: Nutrient Agar. } \\
\text { b Mean sclerotial germination per medium for the three isolates combined }\end{array}$} \\
\hline
\end{tabular}

${ }^{c}$ Mean sclerotial germination per isolate for all media combined
${ }^{*}$ LSD (Culture media $\times$ S. rolfsii isolates $)=5.335 \%$ at $p \leq 0.05$

*For the sclerotial germination of each isolate and for their mean per medium, values followed by the same letter are not significantly different according to Duncan Multiple Range test (at $p \leq 0.05$ ).

Table 8: Sclerotial germination of three Sclerotium rolfsii isolates on eight culture media noted after $24 \mathrm{~h}$ of incubation at $30^{\circ} \mathrm{C}$.

For the data of all culture media combined, the highest number of germinated sclerotia was recorded for $\mathrm{Sr}^{3}$ isolate.

\section{Discussion}

S. rolfsii is a widespread serious pathogen on many economically important crops. Several reports describing its morphological, physiological and pathogenic characterization have been detailed from different countries in the world. Furthermore, exhaustive investigations on the effect of diverse environmental factors influencing growth and survival of $S$. rolfsii such as temperature, soil moisture, $\mathrm{pH}$, and $\mathrm{EC}$ have been conducted. As soil temperature is one of these important factors, the present study investigates the effect of temperature on sclerotia formation, production and germination as well as mycelial growth of three Tunisian isolates of $S$. rolfsii recovered from potato and artichoke. The current study showed that all $S$. rolfsii isolates were able to grow over a range of temperatures ranging between $10^{\circ} \mathrm{C}$ to $35^{\circ} \mathrm{C}$ and no growth was observed at $5^{\circ} \mathrm{C}$ and $40^{\circ} \mathrm{C}$. Optimum radial and dry mycelial growth occurred at $30^{\circ} \mathrm{C}$ for all isolates that showed also good growth at $25^{\circ} \mathrm{C}$. These results are in agreement with other studies reporting that optimum temperature for mycelial growth and dry weight production was $30^{\circ} \mathrm{C}$ [27-29]. Furthermore, other authors also found that $25^{\circ} \mathrm{C}$ to $30^{\circ} \mathrm{C}$ was more conducive for the vegetative growth of $S$. rolfsii [21-23]. In California, this pathogen is most active at relatively warm temperatures ranging between $27^{\circ} \mathrm{C}$ to $32^{\circ} \mathrm{C}$ [24]. Moreover, similar findings have been reported where pathogen mycelial growth was shown to be rapid at $27^{\circ} \mathrm{C}-35^{\circ} \mathrm{C}[9,25]$. However, in another work [30], growth of $S$. rolfsii was maximum at $25^{\circ} \mathrm{C}$ but decreased significantly below $20^{\circ} \mathrm{C}$ and above $35^{\circ} \mathrm{C}$. Sclerotial initiation started on the 3 rd day after incubation at $30^{\circ} \mathrm{C}$ and $35^{\circ} \mathrm{C}$, and mature sclerotia were observed after 15 and 6 days, respectively. All isolates were able to produce sclerotia between $25^{\circ} \mathrm{C}$ and $35^{\circ} \mathrm{C}$. $\mathrm{Sr}^{1}$ showed optimal sclerotial production at $25^{\circ} \mathrm{C}$, which was significantly reduced when temperature increased up to $30^{\circ} \mathrm{C}$ and $35^{\circ} \mathrm{C}$. For $\mathrm{Sr}^{2}$, sclerotial yield was significantly similar at $25^{\circ} \mathrm{C}-35^{\circ} \mathrm{C}$. When grown at $35^{\circ} \mathrm{C}$, the isolate $\mathrm{Sr}^{3}$ showed its maximum production, which was significantly 4 times higher than that recorded at $30^{\circ} \mathrm{C}$ and $25^{\circ} \mathrm{C}$. After 21 days of incubation at $20^{\circ} \mathrm{C}$, all $S$. rolfsii isolates produced very few and scattered mature sclerotia. No mature sclerotia were produced at $5^{\circ} \mathrm{C}, 10^{\circ} \mathrm{C}, 15^{\circ} \mathrm{C}$, and $40^{\circ} \mathrm{C}$. The effect of temperature on sclerotium formation was also examined in other previous studies $[29,31]$ where the optimum temperature for the better sclerotial production ranged from $20^{\circ} \mathrm{C}$ to $30^{\circ} \mathrm{C}$ with a maximum at $25^{\circ} \mathrm{C}$ and where pathogen failed to grow and to produce sclerotia at 10 and $40^{\circ} \mathrm{C}$. Sclerotia were formed since 11 days of incubation at $28^{\circ} \mathrm{C}$ with no variations detected in the number and size of the sclerotia between isolates [32]. However, in the current study, the highest dry weight of 100 sclerotia was recorded at 25 and $30^{\circ} \mathrm{C}$ for $S$. rolfsii isolates $\mathrm{Sr}^{1}$ and $\mathrm{Sr}^{3}$ and decreased at $35^{\circ} \mathrm{C}$. For $\mathrm{Sr}^{2}$, the dry weight of 100 sclerotia was significantly higher at $25^{\circ} \mathrm{C}$ than at $30^{\circ} \mathrm{C}$ and $35^{\circ} \mathrm{C}$. Furthermore, the optimum temperature range for sclerotial germination, noted after $24 \mathrm{~h}$ of incubation on PDA medium, was 
Citation: Ayed F, Jabnoun-Khiareddine H, Aydi Ben Abdallah R, Daami-Remadi M (2018) Effect of Temperatures and Culture Media on Sclerotium rolfsii Mycelial Growth, Sclerotial Formation and Germination. J Plant Pathol Microbiol 9: 446. doi: $10.4172 / 2157-7471.1000446$

Page 8 of 9

fixed at $25^{\circ} \mathrm{C}-35^{\circ} \mathrm{C}$ for all three isolates tested and reached $100 \%$ after $72 \mathrm{~h}$ of incubation. However, sclerotial germination was inhibited at $5^{\circ} \mathrm{C}, 10^{\circ} \mathrm{C}$, and $40^{\circ} \mathrm{C}$, even after $72 \mathrm{~h}$ of incubation. In another study [33], germination of sclerotia was nil at 8 and $40^{\circ} \mathrm{C}$, and estimated at $50 \%-60 \%$ at $15^{\circ} \mathrm{C}-18^{\circ} \mathrm{C}$ and $80 \%-100 \%$ at $21^{\circ} \mathrm{C}-30^{\circ} \mathrm{C}$. Other studies also indicated that sclerotia may degrade rapidly at temperatures exceeding $35^{\circ} \mathrm{C}$ [34]. As well as for temperature, the effect of culture media on $S$. rolfsii growth and survival has been also investigated. In the present study, the suitability of eight culture media was evaluated for fungus growth at $30^{\circ} \mathrm{C}$. For all $S$. rolfsii isolates, optimal radial growth occurred on OAT medium followed by CZA, MYEA and PDA. $\mathrm{SAB}$ and YDA supported also good radial growth of all isolates. The poorest mycelial growth was recorded on NA for $\mathrm{Sr}^{1}$ and $\mathrm{Sr}^{2}$ isolates and on NA and WA for $\mathrm{Sr}^{3}$. Previous studies also showed a similar pattern, in that $S$. rolfsii preferred PDA medium for best growth, followed by MYEA and CZA media [29,35]. Also, among solid media tested for their effects on $S$. rolfsii growth, the highest growth was observed on OAT, PDA and SAB media [28]. Moreover, culture media had an effect on the cultural and morphological characters of $S$. rolfsii isolates. In fact, when grown on PDA and OAT media, $S$. rolfsii developed cottony colonies with abundant mycelium whereas on WA and CZA, growth was thin and scanty. Colonies formed on the other media (SAB, MYEA, YDA and NA media) developed sparse and flat mycelia. All isolates differed in their mycelial dispersion and appearance in Petri plates showing dispersed growth all over the plate to aggregated fashion and their appearance was loose to dense cottony with sparse or fluffy mycelium [36]. Fungal mycelium can adopt flat or cottony type of mycelial growth, on the basis of availability of nutrition, although it may differ between pathogen strains $[37,38]$. Microscopic examination of the fungal culture revealed the aerial hyaline, thin walled, septate hyphae with profusely branched mycelium showing clamp connections. When fungus attained maturity, small mycelial knots were formed which later turned to mustard seed like sclerotia which were deep brown or brownish black, shiny, hard and spherical to irregular in shape [39]. Sclerotial initials were observed from 3 to 9 days after inoculation on all media except NA. This finding confirmed a previous study [40] reporting that the time required for sclerotial initiation was between 4 and 9 days. Results showed that WA and CZA were the most suitable culture media for $S$. rolfsii sclerotial formation as mature sclerotia became brownish at the $9^{\text {th }}$ and $9-12^{\text {th }}$ day after inoculation, respectively. However, sclerotial development was found to be very slow on NA and YDA and no dark brown sclerotia were observed even after 21 days of incubation. On the other media, such as PDA and MYEA, brown mature sclerotia were observed only after 12-15 and 15-21 days, respectively. The highest sclerotial production was noted on $\mathrm{Sr}^{1}$ and $\mathrm{Sr}^{2}$ cultures grown on PDA, followed by $\mathrm{CZA}$, while $\mathrm{Sr}^{3}$ formed significantly more sclerotia on CZA followed by PDA. Therefore, PDA, CZA and MYEA media were assessed for their effect on sclerotial dry weight. Significantly higher 100 sclerotia dry weight was noted on $\mathrm{Sr}^{3}$ culture grown on PDA than on CZA and MYEA, whereas both $\mathrm{Sr}^{1}$ and $\mathrm{Sr}^{2}$ isolates produced significantly comparable 100 sclerotia dry weights on PDA, MYEA and CZA media. Nevertheless, all $S$. rolfsii isolates produced fewer sclerotia when grown on WA and NA whereas YDA did not support any sclerotial formation. Various previous studies also demonstrated the excellent sclerotial production on PDA medium $[29,35]$. The variation of sclerotial production in different media may be attributed to their nutritional factors $[41,42]$. The current study also demonstrated that, among the eight culture media tested, optimal germination was recorded on PDA and MYEA media, followed by YDA, for $\mathrm{Sr}^{1}$ isolate, while that of $\mathrm{Sr}^{2}$ was noted on OAT and YDA media, followed by
MYEA, SAB and WA. PDA, MYEA, OAT, followed by CZA, WA and YDA were the most favorable media for the germination of $\mathrm{Sr}^{3}$ sclerotia. For all isolates tested, the lowest sclerotial germination rate was observed on NA.

\section{Conclusion}

This study determined the effect of some factors on different critical stages of $S$. rolfsii life cycle: mycelial growth, sclerotial production and germination. Although the in vitro studies reported here do not directly simulate the conditions of the natural environment, the results provide an insight to the likely behavior and growth of the pathogen in soil. Further investigations are needed to examine the effect of other selected environmental and nutritional factors on the development of Tunisian phytopathogenic isolates of $S$. rolfsii. Such studies would improve our understanding of the pathogen's population dynamics in soil, and help to implement effective disease control.

\section{Funding Acknowledgements}

This work was funded by the Ministry of Higher Education and Scientific Research in Tunisia through the budget assigned to UR13AGR09-Integrated Horticultural Production in the Tunisian Centre-East, The Regional Research Centre on Horticulture and Organic Agriculture of Chott-Mariem, University of Sousse, Tunisia.

\section{Disclosure Statement}

No potential conflict of interest was reported by the authors.

\section{References}

1. OECD (2015) Agriculture and climate change (September 2015), OECD Publishing, Paris.

2. Anderson PK, Cunningham AA, Patel NG, Morales FJ, Epstein PR, et al. (2004) Emerging infectious diseases of plants: Pathogen pollution, climate change and agrotechnology drivers. Trends Ecol Evol 19: 535-544.

3. Bandyopadhya R, Frederiksen RA (1999) Contemporary global movement of emerging plant diseases. Annals of the New York Academy of Sciences 894: 28-36.

4. Hibar K, Daami-Remadi M, Mahjoub ElM (2007) First report of Pectobacterium carotovorum subsp. carotovorum on tomato plants in Tunisia. Tunisian J Plant Prot 2: 1-5.

5. Rhouma A, Triki MA, Krid S, Tuset JJ, Msallem M (2010) First report of a branch dieback of olive trees in Tunisia caused by a Phoma sp. Plant Dis 94: 636 .

6. Gaaliche B, Chehimi S, Dardouri S, Hajlaoui MR (2018) Health status of the pear tree following the establishment of fire blight in Northern Tunisia. International Journal of Fruit Sciences 18: 85-98.

7. Aycock R (1966) Stem rot and other diseases caused by Sclerotium rolfsii or the status of Rolf's fungus after 70 years. Technical Bulletin/North Carolina Agricultural Experiment Station 174: 136-202.

8. Anahosur KH (2001) Integrated management of potato Sclerotium wilt caused by Sclerotium rolfsii. Indian Phytopathol 54: 158-166.

9. Punja ZK (1985) The biology, ecology and control of Sclerotium rolfsii. Annual Rev Phytopathol 23: 97-127.

10. Kator L, Hosea ZY, Oche OD (2015) Sclerotium rolfsii; Causative organism of southern blight, stem rot, white mold and sclerotia rot disease. Ann Biol Res 6: 78-89.

11. Fery RL, Dukes PD (2002) Southern blight (Sclerotium rolfsii Sacc.) of cowpea: Yield-loss estimates and sources of resistance. Crop Prot 21: $403-408$. 
Citation: Ayed F, Jabnoun-Khiareddine H, Aydi Ben Abdallah R, Daami-Remadi M (2018) Effect of Temperatures and Culture Media on Sclerotium rolfsii Mycelial Growth, Sclerotial Formation and Germination. J Plant Pathol Microbiol 9: 446. doi: 10.4172/2157-7471.1000446

Page 9 of 9

12. Anand S, Harikesh BS (2004) Control of collar rot in mint (Mentha spp.) caused by Sclerotium rolfsii using biological means. Current Science 87: 362-366.

13. Banyal DK, Mankotia V, Sugha SK (2008) Soil characteristics and their relation to the development of tomato collar rot caused by Sclerotium rolfsii. Indian Phytopathol 61:103-107.

14. Mccarter SM, Kays SJ (1984) Disease limiting production of Jerusalem artichokes in Georgia. Plant Dis 68: 299-302.

15. Dasgupta MK, Mandal NC (1989) Postharvest pathology of perishables. New Delhi: Oxford and IBH Publisher, P: 623.

16. Elad Y, Pertot I (2014) Climate change impacts on plant pathogens and plant diseases. J Crop Improv 28: 99-139.

17. Boulila M (2001) Le dépérissement de lolivier issu de boutures herbacées en Tunisie. OEPP/EPPO Bull 31: 111- 117.

18. Daami-Remadi M, Jabnoun-Khiareddine H, Ayed F, Hibar K, El Mahjoub M (2007) First report of Sclerotium rolfsii causing atypical soft rot on potato tubers in Tunisia. Tunisian J Plant Prot 2: 59-62.

19. Kalai-Grami L, Mnari-Hattab M, Terres R, Dridi M, Hajlaoui MR (2013) First report of apple collar rot incited by Sclerotium rolfsii in Tunisia. J Plant Pathol 95: S4.71.

20. Abeygunawardena DVW, Wood RKS (1957) Factors affecting the germination of sclerotia and mycelia growth of Sclerotium rolfsii. Trans Brit Mycol Soc 40: 221-231.

21. Mahen VK, Mayer CD, Brennemen TB, McDonald D (1995) Stem and pod rot of groundnut. ICRISAT Information Bulletin 4: 28 .

22. Tripathi BP, Khare N (2006) Growth of Sclerotium rolfsii of chick pea as influenced by bioagents. Ann Plant Prot Sci 13: 492-493.

23. Lin MA, Yin F, Zeng W, Huang Y (2009) Biological characteristics of Sclerotium rolfsii Sacc. in Coptis chinensis and screening on its controlling fungicides. J Anhui Agric Sci 34: 240-245.

24. Browne GT, De Tar WR, Sanden BI, Phene CJ (2002) Comparison of drip and sprinkler irrigation systems for applying metam sodium and managing stem rot on potato. Plant Dis 86: 1211-1218.

25. Daami-Remadi M, Jabnoun-Khiareddine H, Sdiri A, El Mahjoub M (2010) Effect of temperature on Sclerotium rolfsii mycelia growth and rot severity on potato tubers. Afr J Plant Sci Biotechnol 4: 54-58.

26. Maurya S, Singh UP, Singh R, Singh A, Singh HB (2010) Role of air and light in sclerotial development and basidiospore formation in Sclerotium rolfsii. J Plant Prot Res 50: 206-209.

27. Pane A, Raudino F, Adornetto S, Proietto RG, Cacciola SO (2007) Blight and English ivy (Hedera helix) caused by Sclerotium rolfsii in Sicily. Plant Dis 91: 635 .

28. Basamma K, Naik K, Madhura C, Manjunath L (2012) Cultural and physiological studies on Sclerotium rolfsii causing Sclerotium wilt of potato. International Journal of Plant Sciences 7: 216-219.
29. Zape AS, Gade RM, Singh R (2013) Physiological studies on different media, $\mathrm{pH}$ and temperature on Sclerotium rolfsii isolates of soybean. Schol J Agric Sci 2: 238-241.

30. Hussain A, Muhammad IS, Ayub N, Haqqani AM (2006) Physiological study of Sclerotium rolfsii Sacc. Pak J Plant Pathol 2: 102-106.

31. Prasad M, Lakshmi S, Sujata K, Naresh N, chander Rao S (2012) Variability in Sclerotium rolfsii associated with collar rot of sunflower. Indian Phytopathol 65: 161-165.

32. Okereke VC, Wokocha RC (2007) In vitro growth of four isolates of Sclerotium rolfsii Sacc. in the humid tropics. Afr J Biotechnol 6: 1879-1881.

33. Punja ZK, Jenkins SF (1984) Influence of temperature, moisture, modified gaseous atmosphere, and depth in soil on eruptive sclerotial germination of Sclerotium rolfsii. Phytopathology 74: 749-754.

34. Vannacci G, Triolo E, Materazzi A (1988) Survival of Sclerotinia minor Jagger sclerotia in solarised soil. Plant and Soil 109: 49-55.

35. Kumar R, Mishra P, Singh G, Prasad CS (2008) Effect of media, temperature and $\mathrm{pH}$ on growth and sclerotial production of Sclerotium rolfsii. Ann Plant Prot Sci 16: 485-547.

36. Mahato A, Kumar BM (2017) Cultural, morphological and pathogenic variability of different isolates of Sclerotium rolfsii obtained from ricetomato-rice cropping system of undulating red and lateritic zone of West Bengal, India. Inter J Curr Microbiol Appl Sci 6: 1843-1851.

37. Gow NAR, Gadd GM (1995) The growing fungus. Chapman and Hall, London.

38. Sab J , Nagaraja A, Mallikarjun H, Manu TG (2014) Variability among the sclerotium rolfsii Sacc. isolates from southern Karnataka. Int J Agric Sci 5: 229-236.

39. Kumar R, Santhoshi MVM, Krishna TG, Reddy KR (2014) Cultural and morphological variability Sclerotium rolfsii isolates infecting groundnut and its reaction to some fungicidal. Inter J Curr Microbiol Appl Sci 3: 553-561.

40. Manu TG, Nagaraja A, Manjunatha SV (2018) Morphological and cultural variability among the Sclerotium rolfsii isolates. J Pharmacog Phytochem 7: 904-907.

41. Henis Y, Chet I, Hershenzon ZA (1965) Nutritional and mechanical factors involved in mycelial growth and production of sclerotia by Sclerotium rolfsii in artificial medium and amended soil. Phytopathology 55: 87-91.

42. Sulladmath VV, Hiremath PC, Anilkumar TB (1977) Studies on variation in Sclerotium rolfsii. Mysore J Agric Sci 11: 374-380. 